\title{
THE SOUTH AUSTRALIAN MUSEUM
}

$\mathrm{T}$ WE Records of the South Australian Museum (12 1956 ) is an outstanding issue as it includes an illustrated record of the first hundred years, 18561956. The account is compiled by the present director, Mr. H. M. Hale, who has been on the staff since 1914 and is thus able to relate much of the story of this well-known Museum from personal knowledge.

'The establishment of a natural history museum in South Australia was considered at a very early stage in the history of the State, and a Natural History Society formed in 1838 had for its object "the cultivation of the Science of Natural History in all its branches and more especially the Natural History of South Australia". Another potent influence at that time was the Adelaide Philosophical Society founded in 1853. Thus the usual pattern, so often seen in English towns, was set and the South Australian Institute was founded in 1856 . The Institute comprised a library and a museum, and its first Government grant was the modest sum of $£ 350$. Specimens soon accumulated-chiefly geological and entomological--and meanwhile the search for accommodation was pursued with vigour. Eventually a site was procured, and the building was opened, though still incomplete, in 1861. Mr. F. G. Waterhouse was appointed as the. first curator in 1859 at a minimum salary of $£ 50$ rising to a maximum of $£ 200$. Also, then as now, a very small purchase grant made it necessary for the Museum to depend on gifts rather than on grants. Lack of accommodation and financial support soon became apparent and the difficultios of the Board were those common to committees and directors of the present day.

By 1865 Waterhouse had become concerned about the limited exhibition space at his disposal, but it was not until 1873, after prolonged efforts to urge the Government to provide the necessary grants, that the foundations of the west wing extension were laid. It was, however, only in 1882 that the material was placed in the new west wing, the formal opening taking place in 1884 .

In 1883 Dr. Wilhelm Haacke was appointed director, and the change in title of the chief official was accompanied by the renaming of the Institute with its present title of "The South Australian Museum". The mounting of expeditions was one of the major activities of the Museum in that period of its existence, and especial mention must be made of the skeletons of Diprotodon which were found in a water-course near the margin of Lake Callabonna.

It was not long after the occupation of the west wing that the grave disadvantage of having a public library, museum and art gallery in one building became apparent. In 1893 the red brick building which constitutes the north wing of the block was completed and formally opened early in 1895. Thus almost forty years after the founding of the South Australian Institute the Museum was for the first time housed in a building provided solely for that purpose; although the museum, the art gallery and the public library continued to be associated under one board for a further forty-five years.

The next twenty years, 1895-1915, were a period of concentrated effort within the Museum. Expeditions were few and intensive curatorial work by members of the staff placed the now extensive col- lections in good order. Ever since the 'eighties research had been considered as one of the important activities of the South Australian Museum; but in the period after the First World War the staff wrote an increasing number of original papers, particularly for the Proceedings of the Royal Society of South Australia, of which many were Fellows. This activity led to the publication of the Records of the South Australian Museum, containing papers by members of the staff.

The beginning of tho period 1928-40 started with a long-term reorganization of the Museum and ended with the establishment of three new government departments - the library, museum and art gallery. Much surplus material was removed from exhibition and an impression of spaciousness was produced by eliminating some of the 'funeral black' cases. This re-organization was expedited by a visit of a delegation from the Carnegie Corporation of New York. During the years $1940-46$ the Board was faced with the difficulties and responsibilities consequent on the second World War. When Japan entered the War in 1941 a large part of the collection was removed as an air raid precaution to safer storage away from Adelaide. At first the objects were placed in wine cellars scattered in the Mount Lofty Ranges but these proved unsuitable, and after the bombing of Darwin in 1942 a disused railway tunnel provided a more efficient shelter. With a depleted staff this was no light task and much help was given by the honorary officers. The Army Education Service also called for assistance and during one year more than one hundred lectures and demonstrations were given in the Museum, in camps and in hospitals. In addition to these and other duties, the staff carried out much research on war-time problems. The last decade, 1946-56, marked the gradual return of the staff and the initiation of many experiments in exhibition and conservation. The majority of the cases were painted and a new feature was an exhibit concerning game-birds and details of the legislation passed to ensure that these birds were not exterminated. Miniature dioramas were also constructed.

The history concludes with a note concerning the future. It is rightly maintained that the South Australian Museum has outstanding collections and that the improvisations and makeshifts which have been practised for at least fifty years have reached a stage when drastic action is necessary. The conclusion is reached that there is no satisfactory alternative to the erection of a new building, preferably in a landscaped setting, planned to meet modern requirements. Spacious exhibition floors with no supporting pillars and with provision for smaller units by means of movable partitions allowing elasticity for display are rightly considered to be essential.

This is a moving story of a great museum related. in simple language. It is an important contribution to museum literature not only on account of the elaborate details it relates but also as a record of a large nauseum and the trials and difficulties which arose and were overcome. It is a record of the acquisition and conservation, despite set-backs, of the present important collections of ethnological, zoological and mineralogical objects and is in many ways an epitome of the history of the museum movement in all parts of the world.
F. S. WAILIS 